UDC: 616-06

\title{
FUNCTIONAL CLASSES AND CLINICAL CHARACTERISTICS OF CHRONIC HEART FAILURE IN PATIENTS WITH ATRIAL FIBRILLATION AND/OR FLUTTER AFTER RADIOFREQUENCY ABLATION
}

\author{
Zolotarova T. V., Brynza M. S., Yabluchanskiy M. I.
}

V. N. Karazin Kharkiv National University, Kharkiv, Ukraine

The combination of atrial fibrillation and/or flutter and chronic heart failure is a frequent problem for many patients. Radiofrequency ablation is effective in the strategy for controlling the rhythm of patients with atrial fibrillation and/or flutter, but always requires concomitant therapeutic support. The study involved 70 patients with atrial fibrillation and/or flutter after radiofrequency ablation which were divided into groups according to the functional class of chronic heart failure. Gender and age of patients; types of ischemic heart disease; stages of chronic heart failure; degrees of arterial hypertension; the form of atrial fibrillation and flutter; class EHRA; the presence of diabetes mellitus type 1 or 2 we evaluated. The female sex prevailed in the group of II functional class of chronic heart failure than in I functional class or III functional class. Ischemic heart disease, first of all angina of effort, in patients with III functional class of chronic heart failure was significantly more frequent. In group of III functional class of chronic heart failure there were significantly more patients with 3 degrees of arterial hypertension. Male patients, regardless of functional class of chronic heart failure, more often than females are conducted invasive methods of treatment for atrial fibrillation/flutter. With increasing of functional class of angina the functional class of chronic heart failure is increasing. Among patients II and III functional class of chronic heart failure prevails the arterial hypertension III degree, which may be a predictor of adverse prognosis.

KEY WORDS: clinical characteristics, atrial fibrillation; atrial flutter, chronic heart failure, catheter ablation

\section{ФУНКЦІОНАЛЬНІ КЛАСИ ТА КЛІНІЧНІ ХАРАКТЕРИСТИКИ ХРОНІЧНӦ̈ СЕРЦЕВОЇ НЕДОСТАТНОСТІ У ХВОРИХ НА ФІБРИЛЯЦІЮ ТА/АБО ТРІПОТІННЯ ПЕРЕДСЕРДЬ ПІСЛЯ РАДІОЧАСТОТНОЇ АБЛЯЦІї}

\section{Золотарьова Т. В., Бринза М. С., Яблучанський М. І.}

Харківський національний університет імені В.Н. Каразіна, м. Харків, Україна

Поєднання фібриляції (тріпотіння) передсердь та хронічної серцевої недостатності є частою проблемою для багатьох пацієнтів. Радіочастотна абляція ефективна у стратегії контролю ритму пацієнтів 3 фібриляцією та/або тріпотінням передсердь, але завжди вимагає супутньої терапевтичної підтримки. У дослідженні взяли участь 70 пацієнтів з фібриляцією та/або тріпотінням передсердь після радіочастотної абляції, які були розділені на групи відповідно до функціонального класу хронічної серцевої недостатності. Стать і вік пацієнтів; типи ішемічної хвороби серця; ступені артеріальної гіпертензії; форми фібриляції (тріпотіння) передсердь; клас EHRA; наявність цукрового діабету 1 або 2 типу - були оцінені. Жіноча стать переважала у групі II функціонального класу хронічної серцевої недостатності, ніж у I функціональному класі або III функціональному класі. Ішемічна хвороба серця, а, насамперед, стабільна стенокардія, у пацієнтів 3 хронічною серцевою недостатністю III функціонального класу була значно частішою. У групі ІІІ функціонального класу хронічної серцевої недостатності виявилося значно більше пацієнтів 33 ступеню артеріальної гіпертензії. Пацієнтам чоловічої статі, незалежно від функціонального класу хронічної серцевої недостатності частіше, ніж жінкам, проводять інвазивні методи лікування фібриляції/ тріпотіння передсердь. При збільшенні функціонально класу стенокардії функціональний клас хронічної серцевої недостатності зростає. Серед пацієнтів II та III функціонального класу хронічної серцевої недостатності переважає артеріальна гіпертензія 2 ступеню, що може бути предиктором несприятливого прогнозу.

КЛЮЧОВІ СЛОВА: клінічна характеристика, фібриляція передсердь, трепотіння передсердь, хронічна серцева недостатність, катетерна абляція 


\section{ФУНКЦИОНАЛЬНЫЕ КЛАССЫ И КЛИНИЧЕСКИЕ ХАРАКТЕРИСТИКИ ХРОНИЧЕСКОЙ СЕРДЕЧНОЙ НЕДОСТАТОЧНОСТИ У ПАЦИЕНТОВ С ФИБРИЛЛЯЦИЕЙ И/ИЛИ ТРЕПЕТАНИЕМ ПРЕДСЕРДИЙ ПОСЛЕ РАДИОЧАСТОТНОЙ АБЛЯЦИИ}

Золотарева Т. В., Брынза М. С., Яблучанский Н. И.

Харьковский национальный университет имени В.Н. Каразина, г. Харьков, Украина

Сочетание фибрилляции (трепетания) предсердий и хронической сердечной недостаточности является частой проблемой для многих пациентов. Радиочастотная абляция эффективна в стратегии контроля ритма пациентов с фибрилляцией и/или трепетанием предсердий, но всегда требует сопутствующей терапевтической поддержки. В исследовании приняли участие 70 пациентов с фибрилляцией и/или трепетанием предсердий после радиочастотной абляции, которые были разделены на группы в зависимости от функционального класса хронической сердечной недостаточности. Пол и возраст пациентов; типы ишемической болезни сердца; степени артериальной гипертензии; формы фибрилляции (трепетания) предсердий; класс EHRA; наличие сахарного диабета 1 или 2 типа - были оценены. Женский пол преобладала в группе II функционального класса хронической сердечной недостаточности, чем в I функциональном классе или III функциональном классе. Ишемическая болезнь сердца, а, прежде всего, стабильная стенокардия, у пациентов с хронической сердечной недостаточностью III функционального класса была значительно более частой. В группе III функционального класса хронической сердечной недостаточности оказалось значительно больше пациентов с 3 степени артериальной гипертензии. Пациентам мужского пола, независимо от функционального класса хронической сердечной недостаточности, чаще, чем женщинам, проводят инвазивные методы лечения фибрилляции /трепетания предсердий. При увеличении функционально класса стенокардии функциональный класс хронической сердечной недостаточности возрастает. Среди пациентов II и III функционального класса хронической сердечной недостаточности преобладает артериальная гипертензия 2 степени, что может быть предиктором неблагоприятного прогноза.

КЛЮЧЕВЫЕ СЛОВА: клиническая характеристика, фибрилляция предсердий, трепетание предсердий, хроническая сердечная недостаточность, катетерная абляция

\section{INTRODUCTION}

The combination of atrial fibrillation and/or flutter and chronic heart failure is a frequent problem for many patients [1].

These diseases have similar risk factors and common pathophysiology. Chronic heart failure and atrial fibrillation and/or flutter exacerbate each other through mechanisms of cardiac remodeling, activation of neurohumoral mechanisms and insufficient left ventricular function [2-3].

Many studies have shown that the presence of atrial fibrillation and/or flutter is associated with an unfavorable prognosis for chronic heart failure, regardless of the systolic function of the left ventricle [1, 3-4].

During the past three decades, catheter and surgical ablation of AF have evolved from investigational procedures to their current role as effective treatment options for patients with atrial fibrillation. Catheter ablation of atrial fibrillation is even more widely available, and is now the most commonly performed catheter ablation procedure [5-6].

Radiofrequency ablation is effective in the strategy for controlling the rhythm of patients with atrial fibrillation and/or flutter [6-7], but always requires concomitant therapeutic support. The presence of chronic heart failure in these individuals greatly influences the management, especially depending on the functional class of chronic heart failure, but this issue has not been studied too much.

\section{OBJECTIVE}

To evaluate clinical characteristics of chronic heart failure in patients with atrial fibrillation and/or flutter after radiofrequency ablation depending on functional class of chronic heart failure.

\section{MATERIALS AND METHODS}

On the basis SI «Zaycev V. T. Institute of General and Urgent Surgery NAMS of Ukraine», Kharkiv, Ukraine 70 patients with atrial fibrillation and/or flutter at age $61 \pm 8$ (p $(\mathrm{M} \pm \mathrm{sd})$ ) (44 men and 26 women) in the department of ultrasound and clinicalinstrumental diagnosis and minimally invasive interventions were examined. Patients after radiofrequency ablation (RFA) of arrhythmia were divided into groups according to the functional class (FC) of chronic heart failure 
(CHF) according to New York Heart Association (NYHA) Functional Classification: 22 patients with CHF I FC, 29 - II FC, 19 - III FC. Patients IV FC CHF were absent.

We evaluated gender and age of patients; types of ischemic heart disease (IHD) (angina of effort and functional classes (FC) according Canadian Cardiovascular Society, past myocardial infarction (PMI)) [8-9]; CHF stages (I-III) according to the classification of Strazhesko M. D. and Vasilenko V. H., degrees of arterial hypertension (AH) (1-3) [9], the form of $\mathrm{AF}$ and $\mathrm{AFL}$ (paroxysmal, persistent, long-standing persistent, permanent); class EHRA (I-IV) according to the classification of the European Association for Heart Rate [6]; the presence of diabetes mellitus (DM) type 1 or 2 .

The above indicators were evaluated for 5-7 days after surgery. The data obtained after the formation of the database processed in Microsoft Excel, Statistica 10. For statistical evaluation of the results were used parametric criterias (mean - M, standard deviation - sd), non-parametric criterias (absolute (n, number), relative (percentage (\%) and the average error rate $(\mathrm{sP})$ ). The binary data of the independent samples were expressed in parts, the statistical significance of the differences was determined using $\mathrm{t}$ - criteria, the level of significance was set at 0,05 . The reliability of the differences was also confirmed by the method of confidence intervals. The results were considered reliable at levels of significance $\mathrm{p}<0,05$.

The research was carried out within the Scientific research work; ID 0116 U000973 from 12.2016.

\section{RESULTS AND DISCUSSION}

Table presents the data of characteristics of chronic heart failure in patients with $\mathrm{AF} / \mathrm{AFL}$ after ablation depending on the FC CHF.

It was found that most patients were male, but no quantitative differences were found depending on FC CHF.

The female sex prevailed in the group of II FC CHF than I FC or III FC.

IHD in patients with III FC CHF was significantly more frequent than among patients with I FC or II FC.

Angina of effort was significantly more frequent among the group of patients III FC CHF.

Among group of I FC CHF was predominated angina of effort II FC, among group II FC CHF in more than a percentage of cases registered angina of effort III FC; among group III FC CHF - angina of effort III FC and PMI.

Depending on the stage of CHF, in all three groups, patients with II A stage CHF predominated.

Among the whole group of patients with AH, 3 degrees were observed more often than 1 degree. Most significantly $\mathrm{AH}$ was registered among the group II FC CHF and III FC CHF than among those belonging to group I FC.

In group III of FC CHF there were significantly more patients with 3 degrees of $\mathrm{AH}$, in group I and II of FC CHF there were no significant differences depending on the degree of hypertension.

In the whole group of patients, AF was dominant, and the persistent form was the most common.

The frequency of detection of AF, depending on FC CHF, had no significant differences.

Within the groups of FC CHF differences in the form (paroxysmal, persistent, long-standing persistent, permanent), there are no significant differences, except for the group II FC, where greater proportion had persistent form.

Among surveyed significant differences in the frequency of AFL detection in different groups of FC CHF were not found.

Persistent form of AFL prevailed over others; it was at the same frequency in all groups of FC CHF.

By classes EHRA in all $\mathrm{FC} \mathrm{CHF}$ is significantly prevailing III class; IV class EHRA is more common in group III FC CHF.

In all groups patients with type 1 diabetes were absent. Type 2 diabetes occurred only in patients with III FC CHF.

Based on our results, interventions due to $\mathrm{AF} / \mathrm{AFL}$ are performed more often in male patients, but this is independent from FC CHF. In a study by Schnabel R.B. and others [6] were showed that women were more symptomatic but less likely to receive invasive methods for restoring the rhythm, such as electrical cardioversion or ablation. Further research is needed to confirm that these differences do not impede women with AF/AFL.

II FC CHF was prevailed among women who had ablation. This feature is not found in the literature, therefore, requires further research. 
Clinical characteristics of chronic heart failure in patients with AF/AFL

Table after ablation depending on the FC CHF

\begin{tabular}{|c|c|c|c|c|c|c|}
\hline \multirow{2}{*}{\multicolumn{3}{|c|}{ Clinical data }} & \multirow{2}{*}{ Total } & \multicolumn{3}{|c|}{$\mathrm{FC} \mathrm{CHF}$} \\
\hline & & & & I FC & II FC & III FC \\
\hline \multicolumn{3}{|c|}{ Number $(\mathrm{n}, \% \pm \mathrm{sP})$} & 70 & $22(31,5 \pm 6)$ & $29(41,4 \pm 5)$ & $19(27,1 \pm 5)$ \\
\hline \multicolumn{3}{|c|}{ Age, years $(M \pm s d)$} & $61 \pm 8$ & $56 \pm 8$ & $62 \pm 8$ & $65 \pm 8$ \\
\hline \multirow{2}{*}{$\begin{array}{c}\text { Gender } \\
(\mathrm{n}(\% \pm \mathrm{sP}))\end{array}$} & \multicolumn{2}{|l|}{ Males } & $\begin{array}{c}44 \\
(62,8 \pm 5,8) \cdot \\
\end{array}$ & $\begin{array}{c}14 \\
(31,8 \pm 7,1) \\
\end{array}$ & $\begin{array}{c}16 \\
(36,4 \pm 7,3) \\
\end{array}$ & $\begin{array}{c}14 \\
(31,8 \pm 7,1) \\
\end{array}$ \\
\hline & \multicolumn{2}{|c|}{ Females } & $26(37 \pm 6) \bullet$ & $\begin{array}{c}8 \\
(30,7 \pm 7,2)\end{array}$ & $\begin{array}{c}13 \\
(50 \pm 10) * *\end{array}$ & $\begin{array}{c}5 \\
(19,2 \pm 7,5) * *\end{array}$ \\
\hline \multirow{7}{*}{$\begin{array}{c}\text { IHD } \\
(\mathrm{n}(\% \pm \mathrm{sP}))\end{array}$} & \multicolumn{2}{|l|}{ Total } & $26(100)$ & $\begin{array}{c}4 \\
(15,4 \pm 7,2) \\
\end{array}$ & $\begin{array}{c}5 \\
(19,2 \pm 7,9) \\
\end{array}$ & $\begin{array}{c}17 \\
(65,4 \pm 9,5) *\end{array}$ \\
\hline & \multicolumn{2}{|c|}{ Angina of effort } & 22 & $\begin{array}{c}4 \\
(18,2 \pm 8,4)\end{array}$ & $\begin{array}{c}6 \\
(27,3 \pm 9,7) \\
\end{array}$ & $\begin{array}{c}12 \\
(54,5 \pm 10,9) * *\end{array}$ \\
\hline & \multirow{4}{*}{ FC of angina } & $\mathrm{I}$ & $1(5 \pm 3)$ & $1(25 \pm 5)$ & - & - \\
\hline & & II & $9(43 \pm 6)$ & $3(75 \pm 5)$ & $2(33 \pm 6)$ & $4(33 \pm 6)$ \\
\hline & & III & $11(52 \pm 6)$ & - & $4,67 \pm 6$ & $8,67 \pm 6$ \\
\hline & & IV & - & - & - & - \\
\hline & \multicolumn{2}{|l|}{ PMI } & $5(19 \pm 5)$ & - & - & $5(29 \pm 5)$ \\
\hline \multirow{4}{*}{$\begin{array}{l}\text { CHF stages } \\
((\mathrm{n}(\% \pm \mathrm{sP}))\end{array}$} & \multicolumn{2}{|l|}{$\mathrm{I}$} & $29(41 \pm 6)$ & $22(100)$ & $7(24 \pm 5)$ & - \\
\hline & \multicolumn{2}{|l|}{ II A } & $34(49 \pm 6)$ & - & $22(76 \pm 5)$ & $12(63 \pm 6)^{\Delta}$ \\
\hline & \multicolumn{2}{|l|}{ II B } & $7(10 \pm 4)$ & - & - & $7(37 \pm 6)$ \\
\hline & \multicolumn{2}{|l|}{ III } & - & - & - & - \\
\hline \multirow{4}{*}{$\begin{array}{c}\mathrm{AH} \\
(\mathrm{n}(\% \pm \mathrm{sP}))\end{array}$} & \multicolumn{2}{|l|}{ Total } & $41(59 \pm 6)$ & $\begin{array}{c}9 \\
(21,9 \pm 6,5)^{* *}\end{array}$ & $\begin{array}{c}18 \\
(43,9 \pm 7,8) * *\end{array}$ & $\begin{array}{c}14 \\
(34,1 \pm 7)\end{array}$ \\
\hline & \multirow{3}{*}{ Degree } & $\mathrm{I}$ & $2(5 \pm 3)$ & - & $2(11 \pm 4)$ & 0 \\
\hline & & II & $16(39 \pm 6) \bullet$ & $6(67 \pm 6)$ & $7(39 \pm 6)$ & $\begin{array}{c}3 \\
(21 \pm 5) \bullet \\
\end{array}$ \\
\hline & & III & $23(56 \pm 6) \bullet$ & $3(33 \pm 6)$ & $9(50 \pm 6)$ & $\begin{array}{c}11 \\
(79 \pm 5)\end{array}$ \\
\hline \multirow{5}{*}{$\begin{array}{c}\mathrm{AF} \\
(\mathrm{n}(\% \pm \mathrm{sP}))\end{array}$} & \multicolumn{2}{|l|}{ Total } & $\begin{array}{c}51 \\
(72,8 \pm 5,3) \\
\end{array}$ & $\begin{array}{c}16 \\
(31,4 \pm 6,5)\end{array}$ & $\begin{array}{c}21 \\
(41,2 \pm 6,9) \\
\end{array}$ & $\begin{array}{c}14 \\
(27,4 \pm 6,3)^{\Delta}\end{array}$ \\
\hline & \multicolumn{2}{|c|}{ Paroxysmal } & $\begin{array}{c}15 \\
(29,4 \pm 6,4) \\
\end{array}$ & $\begin{array}{c}6 \\
(38,0 \pm 12,5) \\
\end{array}$ & $\begin{array}{c}5 \\
(23,8 \pm 9,5) \cdot \bullet \\
\end{array}$ & $\begin{array}{c}4 \\
(28,6 \pm 12,5) \\
\end{array}$ \\
\hline & \multicolumn{2}{|c|}{ Persistent } & $\begin{array}{c}31 \\
(60,8 \pm 6,9) \cdot \bullet\end{array}$ & $\begin{array}{c}10 \\
(63 \pm 12,5) \\
\end{array}$ & $\begin{array}{c}15 \\
(71,4 \pm 10,1) \bullet \\
\end{array}$ & $\begin{array}{c}6 \\
(42,9 \pm 13,7) \\
\end{array}$ \\
\hline & \multicolumn{2}{|c|}{$\begin{array}{l}\text { Long-standing } \\
\text { persistent }\end{array}$} & - & - & - & - \\
\hline & \multicolumn{2}{|c|}{ Permanent } & $5(10 \pm 4)$ & - & $1(5 \pm 3)$ & $4(29 \pm 5)$ \\
\hline & Total & & $\begin{array}{c}44 \\
(63 \pm 6) \\
\end{array}$ & $\begin{array}{c}15 \\
(34,1 \pm 7,2) \\
\end{array}$ & $\begin{array}{c}18 \\
(40,9 \pm 7,5) \\
\end{array}$ & $\begin{array}{c}11 \\
(25 \pm 6,6)\end{array}$ \\
\hline & Paroxysm & & $\begin{array}{c}7 \\
(16 \pm 5,5) \bullet\end{array}$ & $\begin{array}{c}3 \\
(20 \pm 10,7) \bullet\end{array}$ & $\begin{array}{c}3 \\
(16,7 \pm 9) \bullet\end{array}$ & $\begin{array}{c}1 \\
(9 \pm 9) \bullet\end{array}$ \\
\hline $\begin{array}{c}\text { AFL } \\
(n(\% \pm s P))\end{array}$ & Persisten & & $35(80 \pm 6,2) \bullet \bullet$ & $\begin{array}{c}11 \\
(73,3 \pm 11,8) \bullet\end{array}$ & $\begin{array}{c}15 \\
(83,3 \pm 9) \bullet^{\Delta}\end{array}$ & $\begin{array}{c}9 \\
(81,9 \pm 12,2) \bullet^{\Delta}\end{array}$ \\
\hline & $\begin{array}{r}\text { Long-stand } \\
\text { persisten } \\
\end{array}$ & & $\begin{array}{c}2 \\
(5 \pm 2) \\
\end{array}$ & $\begin{array}{c}1 \\
(7 \pm 3) \\
\end{array}$ & - & $\begin{array}{c}1 \\
(9 \pm 9) \\
\end{array}$ \\
\hline & Permaner & & - & - & - & - \\
\hline & I & & - & - & - & - \\
\hline & II & & $\begin{array}{c}4 \\
(6 \pm 3)^{*} \\
\end{array}$ & $3(14 \pm 4) \bullet$ & $1(3 \pm 2) \bullet$ & - \\
\hline$(\mathrm{n}(\% \pm \mathrm{sP}))$ & III & & $61(87 \pm 4) \bullet$ & $19(86 \pm 4) \cdot{ }^{\Delta}$ & $\begin{array}{c}27 \\
(93 \pm 3) \cdot{ }^{\Delta} \\
\end{array}$ & $\begin{array}{c}15 \\
(79 \pm 5) \cdot \Delta \\
\end{array}$ \\
\hline & IV & & $5(7 \pm 3) *$ & - & $1(3 \pm 2)$ & $\begin{array}{c}4 \\
(21 \pm 5) \cdot\end{array}$ \\
\hline DM (n & Type & $\mathrm{I}$ & - & - & - & - \\
\hline$(\% \pm \mathrm{sP}))$ & 1уре & II & $4(6 \pm 3)$ & - & - & $4(21 \pm 5)$ \\
\hline
\end{tabular}

Note: $M$-mean; $n$ - number; $s d$ - standard deviation; $s P$ - the average error rate; ${ }^{\Delta-} p>0,05$ the difference between FCs; $\bullet p<0,05$ the difference inside the group, $F C ; \bullet p=0,001$ the difference inside the group, $F C$; $* * p<0,05$ between FC; $* p=0,001$ between FC. 
Angina of effort was prevalent in patients of III FC CHF. FC CHF and FC of agina had a direct dependence: with the growth of $\mathrm{FC}$ angina the $\mathrm{FC} \mathrm{CHF}$ grew. This fact can be explained [7] that AF/AFL is associated with a higher severity of IHD, which can lead to CHF through the progression of IHD and changes in the left ventricle function. In his time Davies M. J. and Pomerance A. in their study on deceased patients with AF suggested that patients with IHD had a primary risk of developing AF/AFL than CHF, which was also reflected in the study by Motloch J. and others [8].

Our study showed that patients with II and III FC CHF more often had an AH III degree and, as shown in the Sahle B.W. study and others [9], these patients have an unfavorable prognosis, especially for males.

We found the predominance of the persistent AF/AFL form over the other in all groups of FC $\mathrm{CHF}$ associated with a poorer rhythm control in this form with medication therapy as were shown in the study of Mittal S. et al. [10].

It has been found that in patients with III FC CHF, according to EHRA, arrhythmia has a more severe course clinically, that has not yet been adequately studied.

\section{CONCLUSIONS}

1. Male patients regardless of the functional class of chronic heart failure more often than females invasive methods of treatment for atrial fibrillation and/or flutter are conducted.

2. Angina of effort is more commonly observed in patients of III functional class of chronic heart failure; functional class of chronic heart failure is increasing with increasing of the functional class of angina.

3. Among patients II and III of functional class of chronic heart failure prevails arterial hypertension III degree, which may be a predictor of adverse prognosis.

4. Regardless of the functional class of chronic heart failure, the persistent form of atrial fibrillation and/or flutter predominates over other forms, due to the poor control of the rhythm by drug therapy.

In the III functional class of chronic heart failure, according to EHRA, the clinical manifestation of arrhythmia is more severe.

\section{PROSPECTS FOR FUTURE RESEARCHES}

It seems to be appropriate to study further clinical course of AF and AFL after RFA at various stages depending on the $\mathrm{FC}$ of $\mathrm{CHF}$ and to find is there are specific characteristics of drug therapy.

\section{REFERENCES}

1. Kotecha D. Atrial fibrillation in heart failure: what should we do? / D. Kotecha, J. P. Piccini. // European Heart Journal. - 2015. - No. 36. - P. 3250-3257.

2. Clinical characteristics and prognostic impact of atrial fibrillation in patients with chronic heart failure [Electronic source] / [L. Gigli, P. Ameri, G. Secco et al.] // World journal of cardiology. - 2016. - Link: https://www.wjgnet.com/1949-8462/journal/v8/i11/index.htm.

3. 2016 ESC Guidelines for the management of atrial fibrillation developed in collaboration with EACTS The Task Force for the management of atrial fibrillation of the European Society of Cardiology (ESC) [Electronic source] // European Heart Journal. - 2016. - Link: http://eurheartj.oxfordjournals.org/content/ehj/early/2016/09/08/eurheartj.ehw210.full.pdf

4. 2013 ESC Guidelines on the management of stable coronary artery disease: the Task Force on the management of stable coronary artery disease of the European Society of Cardiology (ESC) // Journal of Heart Failure. - 2013. - No. 34. - P. 2949-3003.

5. 2016 ESC Guidelines for the diagnosis and treatment of acute and chronic heart failure: The Task Force for the Diagnosis and Treatment of Acute and Chronic Heart Failure of the European Society of Cardiology (ESC) // Journal of Heart Failure. - 2016. - No. 37. - P. 2129-2200.

6. Gender differences in clinical presentation and 1-year outcomes in atrial fibrillation / [R. B. Schnabel, L. Pecen, F. M. Ojeda et al.]. // British Cardiac Society. - 2017. - No. 103. - P. 1024-1030.

7. Corradi D. Atrial fibrillation from the pathologist's perspective / Domenico Corradi. // Cardiovascular Pathology. - 2014. - No. 23. - P. 71-84.

8. Characteristics of coronary artery disease among patients with atrial fibrillation compared to patients with sinus rhythm [Electronic source] / [L. J. Motloch, S. Reda, R. Larbig et al.] // Hellenic Journal of Cardiology. - 2017. - Link: http://dx.doi.org/10.1016/j.hjc.2017.03.001. 
9. Long-term survival following the development of heart failure in an elderly hypertensive population [Electronic source] / [B. W. Sahle, A. J. Owen, L. M. Wing et al.] // Cardiovascular Therapeutics. - 2017. - Link: http://onlinelibrary.wiley.com/doi/10.1111/1755-

5922.12303/abstract;jsessionid=23E24499751AC29865AC14B77901DD71.f03t03.

10. Mittal S. Differentiating Paroxysmal From Persistent Atrial Fibrillation / Suneet Mittal. // Journal of the American College of Cardiology. - 2014. - No. 63. - P. 2849-2851. 